\title{
Pílulas, posts e piadas: a brevidade como éthos da poesia brasileira
}

\author{
Pills, posts and jokes: \\ conciseness as the ethos of Brazilian poetry \\ Píldoras, posts y chistes: \\ la brevedad como éthos de la poesía brasileña
}

Sergio Guilherme Cabral Bento*

\section{Resumo}

O presente artigo se propõe a analisar a origem e os desdobramentos do poema curto na literatura brasileira, desde os seus precursores no século XIX até o seu uso na contemporaneidade. Essa concisão poemática, geralmente associada ao humor, ganharia, no Modernismo, epítetos como "piada", "pílula", "comprimido" e "minuto", e graças a sua vasta proliferação, tornou-se - não sem polêmicas e detratações - uma espécie de gênero recorrente na produção poética nacional. Sua experiência de leitura difere da fruição do verso tradicional, pois é fluida e de compreensão imediata, flash linguístico que desestabiliza o discurso corrente do utilitarismo cotidiano e capta o leitor em um instante catártico a partir da deflagração do riso e/ou da percepção do insurgente valor conceitual inerente ao "poema-piada". Como suas possíveis modulações, o poema concreto, a geração marginal e a poesia publicada nas redes sociais contemporâneas são investigados.

Palavras-chave: poema-piada, leitura de poesia, poesia moderna, poesia contemporânea.

\section{Abstract}

This paper aims to analyze the origin and the development of the short poem in Brazilian literature, from its precursors in nineteenth century to its spread usage nowadays. Such poetic succinctness is usually associated to humor, and was called, in Modernism, as "joke", "pill" and "minute" poetry. Thanks to its wide propagation, it became a kind of recurrent genre in Brazilian poetry, not in an undisputed way, though. Its reading experience differs to the traditional verse's one since it is fluid and immediately comprehensible, as a "flash" that destabilizes the usual speech of everyday usefulness and captures the reader in a cathartic instant by causing the laughter and/or the perception of its rebellious conceptual value, which is inherent to the "joke poems". As possible manifestations, the concrete poem, the "marginal generation" and poetry posted in current social networks are investigated.

Keywords: joke poem, poetry reception, modern poetry, contemporary poetry.

\section{Resumen}

El presente trabajo se propone analizar el origen y los desdoblamientos del poema corto en la literatura brasileña, desde sus precursores en el siglo XIX hasta su uso en la contemporaneidad. Esta concisión poemática, generalmente asociada al humor, ganaría, en el Modernismo, epítetos como "chiste", "píldora", "comprimido" y "minuto", y gracias a su vasta proliferación, se volvió-no sin polémicas y detrataciones - una especie de género recurrente en la producción poética nacional. Su experiencia de lectura difiere de la fruición del verso tradicional, pues es fluida y de comprensión inmediata, flash lingüístico que desestabiliza el discurso corriente del utilitarismo cotidiano y capta al lector en un instante catártico a partir de la deflagración de la risa y / o de la percepción del insurgente valor conceptual inherente al "poema-chiste". Como sus posibles modulaciones, el poema concreto, la generación marginal y la poesía publicada en las redes sociales contemporáneas son investigados.

Palabras-clave: poema-chiste, lectura poética, poesía moderna, poesía contemporânea.

\footnotetext{
* Doutor em Teoria Literária e professor da Universidade Federal de Uberlândia (UFU), Uberlândia, MG, Brasil. (Dorcid.org/00000001-8409-2878. E-mail: sergiobento@ufu.br
} 
A poesia brasileira das últimas décadas exibe uma tendência, entre outras, de apresentar poemas curtos, geralmente de leitura rápida e fluída, muitas vezes encerrando um sentido irônico e/ou humorístico, subvertendo a recepção tradicionalmente associada ao fenômeno poético - de fruição detida e complexa - transformando-a em uma apreensão imediata. Algumas obras, como as de Leila Míccolis ou Chacal, têm nessa estética a quase totalidade de suas criações. Outras, como as de José Paulo Paes e Francisco Alvim, são mais heterogêneas, mas nas composições breves atingem maior repercussão crítica. Mesmo autores que se arriscam a peças mais longas costumam entremear tais epigramas em seus livros, fato percebido, por exemplo, em poetas tão diferentes como Ricardo Domeneck e Alberto Pucheu.

Explicar tal fenômeno certamente obriga o retorno ao modernismo de 1922 e o seu conhecido impacto em toda a produção seguinte. Já naquela época, houve tentativas de se definir a natureza desse tipo de produção: "poema-piada", "poema-pílula", "comprimidos", "minutos de poesia". Entretanto, estudos posteriores, a maioria da segundo metade do século XX, viriam a mostrar que manifestações ainda do século XIX anteciparam a brevidade e a irreverência de Oswald de Andrade, Luís Aranha e outros. Duas delas interessam especialmente a este trabalho, por conta da abreviação receptiva que propõem: os poemetos de Bernardo Guimarães e Qorpo Santo.

O primeiro, romancista de pouca relevância estética no Romantismo brasileiro, poeta lírico inferior a diversos outros de sua geração, possui em sua obra satírica o seu ponto alto. Navega pelas camadas humorísticas desde o grotesco, em "A orgia dos duendes", passando pela paródia do universo fabular, em "A origem do mênstruo", chegando ao nonsense dos "Disparates rimados", série de seis micropoemas independentes, ligados por um fragilíssimo fio condutor marcado em termos coesivos como "também" e "este", embora semanticamente não haja conexões possíveis. Destaca-se o rígido esquema rítmico e métrico, que garante a musicalidade que embala a ausência de sentido:

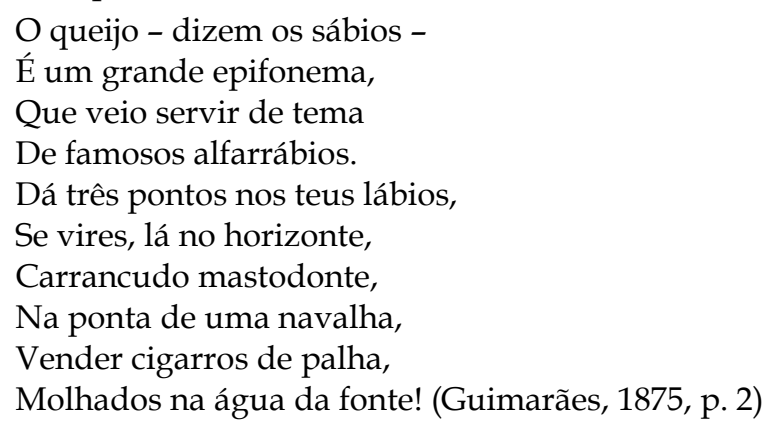

Foi Antonio Candido, em seu clássico Formação da literatura brasileira, o primeiro a notar a modernidade dos procedimentos cômicos de Guimarães, embora de maneira vaga. Em texto mais aprofundado, Paulo Franchetti (1987, p. 12-13) diferencia o poeta dos outros românticos, ressaltando a natureza da "ordenação do discurso em seu, por assim dizer, estado puro" e da "escrita automática avant la lettre". Há um curto-circuito nesses poemas: a coerência sintática e a formatação poemática em redondilha maior fazem o leitor buscar uma significação, um eixo de compreensão impossibilitado pela escolha lexical. Não há intenção simbólica ou metafórica nesse estranhamento, mas apenas lúdica. Nessa mesma linha crítica, Candido (1993), em outro texto, associa tais versos à ininteligibilidade do anfiguri, e pondera que o recurso da associação livre faz de Guimarães um antecipador de métodos do Surrealismo e do Dadaísmo. Se expandirmos a relação ao Modernismo brasileiro, podemos afirmar que o poeta romântico em questão concentra, em germe, aspectos que seriam imprescindíveis ao poema-piada: o tom baixo do poético a partir do humor (também reconhecível, no século XIX, em Sapateiro Silva e Luis Gama); a concisão ferrenha, esta provavelmente inédita na poesia brasileira até então; o caráter conceitual, do texto como performance de ideias; e a experiência breve e fugaz de leitura, diferente da fruição poética tradicional da época.

Já Qorpo Santo demoraria mais a ser descoberto pela crítica, até pela pouca disponibilidade de seus escritos, que ainda vêm sendo localizados. Seu projeto maior, a Ensiqlopèdia ou Seis mezes de huma enfermidade, de nove volumes, possui dois tomos 
desconhecidos. Os outros foram disponibilizados nos últimos anos, e mostram um autor que vai além do dramaturgo insólito de peças antes já divulgadas. Há, nessa obra, uma pletora de anotações banais que lembram um diário; poemas longos e grandiloquentes; poemas curtos de diversos tipos; textos refletindo sobre questões jurídicas, literárias e diversos outros temas; e frases aforísticas, tudo entremeado sem uma organização aparente.

Seus epigramas, de difícil categorização, geralmente ancoram-se na relação sonora entre termos, em um confronto vocabular que gera estranhamento imediato:

Mote

Vieram-me trêtas

Vieram-me letras (Santo, 1877a, p. 38).

O paralelismo quase total entre os dois versos ressalta seus caracteres dissonantes, cuja troca implica em um jogo chistoso: "trêta", à época, referia-se a uma estratégia qualquer de sucesso na esgrima e, por extensão, a uma artimanha que se faz acerca de algo. "Vieram-me trêtas", no sentido de tive ideias, bolei estratagemas. A segunda frase, espelhando a primeira e inserindo o termo "letra", opera a artimanha, a "trêta" no próprio tecido do texto, ou seja, o poema ardiloso, que aparenta simplicidade e despretensão, mas que carrega em si sua própria solução hermenêutica. É, portanto, um poemeto performático, cujo significante realiza o significado e o corporifica. Ao leitor falante de português, a percepção da paronímia garante a comunhão cômica, a "singularidade comum da paróquia" fundamental ao fenômeno do riso, constatada por Bergson (2007), que, nesse caso, brota da desautomatização do código linguístico na assimilação da intensa semelhança entre os dois sintagmas.

Não é necessário apontar a nítida semelhança com a experiência de leitura de "amor/humor", de Oswald de Andrade, talvez o mais célebre poema-piada do Modernismo brasileiro. Além do gracejo, ambos desmistificam a fruição tradicional, circular, recorrente que a poesia costuma exigir. Em Bernardo Guimarães, o nonsense atenua o caráter de "pílula", pois tende-se a reler a peça em busca de coerência semântica. Já Qorpo Santo compacta o discurso sem prejuízo de seu sentido, antecipando elementos amplamente explorados pela poesia Pau-Brasil:

Dito

Antigo é o dito;

- Sempre ri-s'o diabo,

Quando infeliz pobre

- Ao feliz dá; ao rico! (Santo, 1877a, p. 5).

A partir do material cotidiano da língua - nesse caso, o provérbio "Ri-se o diabo quando o faminto dá ao farto"1 -, obtém-se o epigrama, cuja comicidade brota da substituição da oposição "faminto/farto" por outras duas, "feliz/infeliz" e "rico/pobre", atualizando o adágio à lógica monetária do capitalismo, em que ter dinheiro, e não apenas comida, é o que garante satisfação. Aqui, como em Oswald e outros modernistas, o comprimido poético ganha tonalidade social, o que se repete amiúde nos escritos do gaúcho oitocentista, embora com menos empatia humanista: são comuns tercetos e quartetos ridicularizando escravos e serviçais. A heterogeneidade temática e ética é visível ao longo da Ensiqlopèdia, até por ser um apanhado de textos compostos em momentos muito diversos da vida do autor.

Também chama a atenção a presença de frases aforísticas que oscilam entre registros banais, lugares-comuns (como "Quem faz sacrifícios - alcança sempre benefícios", em Santo, 1877b, p. 61) e pensamentos que desvelam o modo como encara a literatura. Alguns desses, como "Apeteci amendoins: com cada um engulo hum pensamento em proza" (Santo, 1877b, p. 37), mostram o caráter imediato e casual que micropoemas e sentenças soltas eram concebidas: a metáfora do amendoim é paradigmática, por remeter ao poder da multiplicidade de pequenos elementos, que juntos compõem uma experiência contínua, porém fragmentada e intervalar. Impossível

${ }^{1}$ Dito corrente no século XIX (Rolland, 1941, p. 41). 
não lembrar da "poesia-cocteil", expressão de Mário de Andrade que aglutina as ideias de leveza e casualidade.

Tal análise da antecipação oitocentista de preceitos modernos, geralmente tidos como uma conquista exclusiva e inédita dos partícipes da Semana de Arte Moderna, poderia ser ampliada a partir de outros autores, como Sousândrade e Luiz Gama. Mas são Bernardo Guimarães e, principalmente, Qorpo Santo que introduzem a concisão epigramática e a leitura imediata no horizonte da poesia brasileira, recorte que nos cabe. É quase certo que a maior parte desses "precursores" fosse desconhecida dos desbravadores da década de 20, inspirados, como se sabe, em modelos da Vanguarda Europeia. A revisitação crítica anticanônica, porém, tem relativizado esse suposto caráter "revolucionário", sem prejuízo às incalculáveis contribuições de tal geração, mas inserindo-a em uma lógica modernizante que já pulsava no século anterior, ainda que à margem.

De qualquer forma, é a lufada renovadora a partir de 1922 que imprime a brevidade poemática como o paradigma mais recorrente da produção posterior. Os próprios participantes do movimento ensaiaram tentativas de definição do (supostamente) novo modo de se escrever e ler poesia que ditaria boa parte da criação poética brasileira do século XX. Paulo Prado, em "Poesia Pau-Brasil", introdução ao Pau Brasil, de Oswald, de 1925, cunha termos que se eternizariam no ideário literário nacional: "Encaixar na rigidez de um soneto todo o baralhamento da vida moderna é absurdo e ridículo" (Prado, 1971, p. 68), afirmava, defendendo um novo lirismo, que orquestrasse a "libertação do verso brasileiro" contra "o mal da eloquência balofa e roçagante" (Prado, 1971, p. 69). Em suma, "Obter, em comprimidos, minutos de poesia" (Prado, 1971, p. 70). Daí nasceram alguns dos epítetos que acompanhariam esse tipo de manifestação: "poema-pílula", "poema-comprimido", "poesiaminuto". As metáforas são bem-sucedidas, pois referem à celeridade e à fragmentação da leitura, rápida decodificação do sentido espremido em poucas linhas.

O texto como um todo, porém, apresenta problemas já amplamente debatidos e repercutidos, como o tom exageradamente celebratório. Conceitualmente, pouco é explicitado além das imagens aludidas. A única aproximação feita é com a brevidade do haicai, que, em sua "concisão lapidar", aproxima-se da premência daqueles dias: "Nesta época apressada de rápidas realizações a tendência é toda para a expressão rude e nua da sensação e do sentimento, numa sinceridade total e sintética" (Prado, 1971, p. 70), no que se segue a citação de um terceto em francês, sem indicação de autoria, referido por Prado como um "haicai japonês": "Le poete japonais / Essuie son couteau: / Cette fois l'éloquence est morte" (Prado, 1971, p. 70).

Paulo Franchetti, pesquisador que tem estudado o haicai e suas representações no Brasil, ocupa-se dessa introdução ao livro de Oswald desvelando seus equívocos. Primordialmente, todas as menções ao formato oriental são inverossímeis, a começar dos versos em língua francesa acima: "Sabemos hoje que o anônimo haikai japonês erguido como bandeira modernista nem era haikai, nem era japonês. No entanto, foi lido como tal por mais de 60 anos" (Franchetti, 2012, p. 196). A autoria, de fato, é de Julien Vocance (pseudônimo de Joseph Seguin), em seu "Art Poétique", de 1921, longo poema em tercetos cujas três primeiras linhas foram apropriadas por Paulo Prado. ${ }^{2}$ Mas essa está longe de ser a principal imprecisão do trecho. Franchetti aponta o caráter singelo do haicai original como inscrição poemática a partir da singularidade da natureza, enfim, um espaço de impressão, sugestão sensória, jamais de pensamento. Da maneira como o poema-piada é a ele associado, atribui-se ao poemeto japonês um "ideal de coloquialidade, de registro direto da sensação e do sentimento e como forma adequada ao tempo rápido do presente" (Franchetti, 2012, p. 196), o que de modo algum se sustenta quando se investiga o seu real teor.

O engano de recepção do haicai parece ser generalizado no Brasil à época, a ponto de um de seus chamados "introdutores" - comumente inserido na geração modernista que cunhou a poesia-minuto -, Guilherme de Almeida, subverter radicalmente seu formato ao atribuir-lhe títulos (algo inexistente na tradição oriental) que lhe adicionam chaves de leitura e orientações

\footnotetext{
${ }^{2}$ A confusão é explicável, pois Julien, anos antes, havia publicado haicais em francês, além de defender a forma japonesa como um exemplo a ser seguido contra a histórica eloquência da poesia de seu país.
} 
semânticas, apagando seu caráter antitemático e transformando-o em um "exercício do virtuosismo, quase como se fosse uma espécie de microssoneto" (Franchetti, 2012, p. 203-204).

Portanto, vê-se que a compreensão da essência daquela forma considerada "revolucionária" era algo obscura, não só pelo desconhecimento de suas manifestações embrionárias no século anterior como pela aderência a modelos equivocadamente interpretados. As próprias nomenclaturas demonstram uma ausência de clareza quanto ao fenômeno. Se o "comprimido", a "pílula" e o "minuto" de Paulo Prado são imagens que remetem à brevidade, o termo "poesiapiada", além da concisão, adiciona a nuance de sentido do humor que brota em poucos versos. Mário de Andrade, em um texto crítico a respeito de Alguma poesia, de Carlos Drummond de Andrade, desvela a origem da expressão, adicionando-lhe um "sinônimo" em verve de ataque:

Em Carlos Drummond de Andrade [...] onde a inteligência prejudicou o poeta e o deformou enormemente, foi em fazer ele aderir aos poemas curtos feitos prà gente dar risada, o poemacocteil, o "poema-piada", na expressão feliz de Sergio Milliet. O poema-piada é um dos maiores defeitos a que levaram a poesia brasileira contemporânea. Antes de mais nada, isso é facílimo: há centenas de criadores de anedotas por aí tudo. Acho mesmo que os poemaspiadas (Manuel Bandeira também caiu, às vezes, nessa precariedade) são a única restrição de valor permanente que se possa fazer a Alguma Poesia. Culpa integral da inteligência. De inteligência incapaz e fatigada ("vou-me embora pra P a sá rg a d a !..." ). Não é mais humour. Não é ainda a sátira. Não creio que esses poemas possam adiantar qualquer coisa ao poeta. E por eles será aplaudido nas rodas dos semi-literarizados das academias e cafés. $\mathrm{O}$ que positivamente é uma desgraça (Andrade, 1974, p. 34-35).

O conhecido rompimento entre o autor de Macunaíma e Oswald de Andrade certamente é o motor de tal radicalidade, embora sua percepção acerca do primeiro livro de Drummond esteja longe de ser incorreta. Mas a boutade, aqui, era direcionada ao rival paulista, cuja figura foi sempre mais colada ao epigrama cômico. O outro termo usado, "cocteil", pode ser entendido tanto como uma banalidade (poemas para festas, como anedotas) quanto em referência à instantaneidade de sua recepção, hors d'oeuvre poético, metáfora então semelhante à pílula.

Mário sabia que o poema-piada nada tinha a ver com a anedota, e que seu mérito, nos casos bem-sucedidos, advinha de seu valor conceitual (como contraposição a uma eloquência vazia) e de sua capacidade articulatória de manipular poucas palavras que transcendessem ao riso ferino, à exposição dos achaques sociais, às aporias do próprio discurso. É bem verdade que a fórmula, como qualquer outra, deixa de ser conceitual quando adotada à exaustão, pois perde o seu trunfo de "choque" e, portanto, sua contundência. Provavelmente por isso que o próprio Oswald, em Cântico dos cânticos para flauta e violão e O escaravelho de ouro, praticamente a abandona.

A reação às pílulas poéticas parece desproporcional se considerarmos apenas a grandiosa obra do autor de Pau-Brasil, mas se torna mais compreensível quando poetas com estilos e qualidades totalmente diversas "derrapam" na tentativa de imitá-las. É nesse sentido que, descontado o exagero, a crítica de Mário de Andrade a Drummond é pertinente, assim como Murilo Mendes, posteriormente, "renegaria" o seu História do Brasil, repleto de investidas cômicas. Em Itinerário de Pasárgada, Manuel Bandeira também faz um mea-culpa:

Piadas... Piadas como mais tarde as faria Murilo Mendes a propósito do rio Paraibuna e da Batalha do Itararé. Por essas e outras brincadeiras estamos agora pagando caro, porque o "espírito de piada", o "poema-piada" são tidos hoje por característica precípua do modernismo, como se toda a obra de Murilo, de Mário de Andrade, de Carlos Drummond de Andrade e outros, eu inclusive, não passasse de um chorrilho de piadas (Bandeira, 1997, p. 339).

O impacto do poema-cocteil fez com que todo o Modernismo fosse a ele associado, apagando outras forças de expressão, e tal rotulagem é que parece incomodar a maioria dos poetas, até porque nenhum deles atingiu, nesse tipo de forma, a energia destruidora dos epigramas oswaldianos. Bandeira, é verdade, reconhece isso, afirmando ser o humor a força motriz daquela poética como um todo, sem prejuízo de sua literariedade: "Mas quem negará a carga de poesia que há nas piadas de Pau Brasil? E por que essa condenação da piada, como se a vida só fosse feita de momentos graves ou se só nesses houvesse teor poético?" (Bandeira, 1997, p. 339). 
O "incômodo" que Oswald causava não se limitou a Mário de Andrade. Além da questão exposta aqui, sua personalidade sabidamente difícil também colaborou para seu isolamento e para o posterior silenciamento que sua obra sofreu, entre as décadas de 30 e 50. É interessante perceber que um crítico arguto como Sérgio Milliet exponha, no mesmo livro, e longe do calor da hora, mas décadas depois, dois julgamentos como os que se seguem:

[...] foi a coragem de romper com a sintaxe convencional, foi o despojamento do falso poético, foi o humor, foi o direito de trocar a imagem comparativa ou alegórica pela imagem direta, foi a revalorização dos qualificativos, etc. Mais, porém, do que influência técnica, houve influência do espírito. [...] Depois de 22 a poesia passa a ser sobretudo emoção (Milliet, 1952, p. 8).

O poema-piada, arma do ataque à falsa solenidade do parnasianismo, ou marca de pudor, logo se transformou em sistema cômodo de fugir à responsabilidade poética. Fui o primeiro (em artigo de 1926) a atacar essa tendência (Milliet, 1952, p. 57).

As duas sentenças demonstram uma contradição, afinal o poema-comprimido parece corresponder a todas as qualidades elencadas por Milliet na primeira citação: rompe com a sintaxe, carrega comicidade, traz imagens diretas e tem justamente no "espírito", naquilo em que sua concepção toca, sua maior conquista. Atacar seus desdobramentos negativos - uma certa "obrigação" de todos os poetas realizarem-no; um abafamento de estéticas mais intimistas ou órficas; um encurtamento brutal na extensão dos poemas brasileiros - não pode significar o desmerecimento da revolução retórica por ele causada e, principalmente, do relevante acervo de ótimas obras em tal formato, não apenas de Oswald, mas de autores menos divulgados, como Luis Aranha ou Ascenso Ferreira, autor do texto que se segue, já escrito na década de 30:

Filosofia

Hora de comer - comer!

Hora de dormir - dormir!

Hora de vadiar - vadiar!

Hora de trabalhar?

- Pernas pro ar que ninguém é de ferro! (Ferreira, 1981, p. 110).

A quebra do paralelismo no último verso desmonta a organização do poema e gera o inesperado cômico, invertendo a lógica do trabalho como regulador da rotina, como baliza cronológica, fenômeno iniciado na Revolução Industrial. A simplicidade do processo de leitura, da experiência estética que tem o fruidor, faz parte do mérito do poema-piada: rapidíssimas inserções poéticas em seu cotidiano, que desmobilizam por alguns momentos a rispidez e o utilitarismo prevalentes no uso do tempo na Modernidade. Enfim, ele é um instante de apreensão do homem pela matéria poética, reconhecimento momentâneo, sempre breve, do "coração" - metáfora da assimilação "da" e "pela" palavra, sabe-la "de cor" -, como sugere Derrida em seu "Che cos'è la poesia" (1992), independentemente da extensão e da quantidade de versos. Nesse caso, além da desautomatização do discurso causada pelo riso, há a implosão iconoclástica ${ }^{3}$ do conceito clássico de poema, metrificado e com vocabulário sofisticado.

A obra de Oswald de Andrade, porém, permaneceria silenciada, o que seria agravado ainda pelos ataques da geração de 45 e pela prevalência do discurso nacionalista de Mário de Andrade como tônica maior do modernismo brasileiro, muito em função da orientação crítica de Antonio Candido como ratificador de tal recorte (Fischer, 2009). Apenas a partir da década de 60 é que os estudos de Benedito Nunes e Haroldo de Campos, e a montagem de O rei da vela pelo Teatro Oficina, reinseririam seu nome na cena literária brasileira. Nunes (1990) foi talvez o primeiro pesquisador a adentrar o vasto trabalho filosófico de Oswald, aclarando o conceito de

\footnotetext{
${ }^{3}$ Franchetti (2013, s.p.) sugere esse valor conceitual do poema oswaldiano, cujo sentido brota de sua "atitude frente à tradição", iconoclasta e dessacralizadora, que depende de um tipo de "pacto" com o leitor: "O que faz deles "poemas' é o gesto que os constituiu como poemas. E a propriedade do gesto, quero dizer: o seu sucesso em ser entendido como um gesto carregado de sentido."
} 
antropofagia em uma chave diferente da de "devoração do outro" - simplificação cristalizada em parte da crítica - colocando-o no horizonte da utopia descolonizadora: o ritual tribalista é a metáfora que faz retornar o pensamento à primitividade, em uma operação de desconstrução do discurso dominante. A partir de tal viés de releitura da teoria antropofágica, os conceitos oswaldianos foram então amplamente difundidos, influenciando, por exemplo, o Tropicalismo e, depois, a teoria do Perspectivismo, de Eduardo Viveiros de Castro.

Já Haroldo de Campos (1974, p. 10) se concentraria na obra poética de Oswald, ressaltando como esta pertence "ao campo específico da linguagem, na medida em que esta poesia afeta, na raiz, aquela consciência prática, real, que é a linguagem". E é na radicalidade dessa posição que ele, segundo o crítico, se diferencia de Mário de Andrade, constituindo-se como o grande nome da primeira lufada modernista. Haroldo, ainda, refuta as críticas de Mário a Pau-Brasil, dizendo que este escreveu "sem ter jamais despegado inteiramente de sua poesia aquele mal da eloquência de que o parnasianismo apenas constituía modalidade estatutária" (Campos, 1974, p. 19) e, por isso, foi incapaz de captar de forma integral a revolução empreendida por Oswald:

Ler a sintética poesia "pau-brasil" à cata de versos de ouro ou pretender que os poemas daquela coletânea inaugural tivessem sido escritos em torno desse efeito, era um esforço de desentendimento: o mesmo que aferir os shots, as tomadas de uma câmara cinematográfica - o camera eye das sínteses oswaldianas - pelos trâmites da burocracia do soneto (Campos, 1974, p. 19-20).

O ponto alto dessa radicalidade é certamente Primeiro caderno de alumno de poesia, em que, além do clássico "amor/humor", veem-se poemetos acompanhados de desenhos, em concisão extrema: "fazenda / o mandacaru espiou a mijada da moça" (Andrade, 1974, p. 163), comprimidos de discurso, instantâneos imagéticos, reforçados pela visualidade dos traços delineados.

O impacto dessa revisitação da obra de Oswald é nítido pelo fato de ela estar na base primordial de influências dos dois maiores tour de force da poesia brasileira da segunda metade do século XX: o concretismo e a geração marginal. É de se espantar que estéticas tão antagônicas, e que protagonizaram os polos extremos da dicotomização que tomou de assalto a cena poética nacional por algumas décadas, tenham bebido tão intensamente na mesma fonte. Silviano Santiago aclara essa aparente contradição:

Enquanto os concretos punham todo o peso numa certa máquina do poema em Oswald de Andrade, num poema que deixava de ser mais e mais um produto fabricado pelo homem para ser quase que um produto cibernético, os poetas da geração mimeógrafo, creio, em vez de ver Oswald de Andrade como aquele autor que faz versos quase que com a perfeição de uma máquina [...]. Os marginais retomam de Oswald de Andrade o coloquialismo, a grande liberdade na construção do verso, do poema, e retomam dele, também, a ideia de que você não precisa necessariamente, para fazer um grande poema, fazer um poema longo (Santiago, 1989, p. 120).

De fato, a citação a Oswald no plano-piloto dos concretos se dá ao lado de Apollinaire e João Cabral de Melo Neto, citando a frase de Paulo Prado já discutida: "em comprimidos, minutos de poesia". No mesmo documento, fala-se em "poesia-produto" e "objeto útil" (Campos, Campos e Pignatari, 1958), de onde se depreende a intenção de associar o poema concreto não apenas à brevidade do poema-piada, como ao seu caráter instantâneo de leitura: "a comunicação mais rápida (implícito um problema de funcionalidade e de estrutura)" (Campos, Campos e Pignatari, 1958).

Há alguns problemas em tais correlações: a "verbivocovisualidade" dos "produtos" concretos certamente herdam o fator conceitual dos poemetos oswaldianos, mas de maneira alguma se inserem na lógica da experiência da instantaneidade receptiva de que tratamos neste estudo. Mesmo aos olhos do leitor contemporâneo - mas principalmente ao fruidor da época -, a visualidade, a fragmentação da ideia e a pulverização espacial da sintaxe impõem desafios de compreensão que exigem leituras múltiplas, mudanças de direção, associações entre sintagmas e até entre letras que se distanciam substancialmente da concepção da "pílula" poética.

Além disso, toda a dimensão contestadora contida nos epigramas modernistas é perdida nas primeiras criações dos concretistas - anteriores ao chamado "salto participante" (abertura 
concedida à incorporação da temática social) -, em que certa sedução pelo desenvolvimentismo industrial pulsante na década de 50 deixa transparecer um desejo de inserção daquela produção literária na lógica do consumo. É nesse sentido que o termo "produto" torna-se revelador, o poema como objeto "útil", tornado mais uma peça na engrenagem capitalista (Hollanda, 2004). Embora tenham abandonado esse discurso rapidamente, é fato que os irmãos Campos e Décio Pignatari, no momento da concepção fundamental de sua teoria, apropriaram-se do poemapiada de maneira incompleta e, pior, subvertendo seu cunho descolonizador e insurgente em direção a uma postura integrada ao status quo.

Já a geração dita marginal, surgida entre os anos 60 e 70, revitaliza aspectos do poema-piada em boa parte de sua criação. Não são poucos os poetas que citam Oswald como uma referência fundamental, como Cacaso e Chacal. Este, em entrevista a Sergio Cohn, afirma:

Eu sempre gostei muito de escrever, tinha essa obsessão pela palavra, mas a poesia era algo distante. Com o Oswald é que me aproximei, porque ele me trouxe a ideia da poesia instantânea, aquela coisa fotográfica de você registrar um instante através de poucas palavras. Eu comecei a escrever muito próximo daquela poética dele, do "poema Kodak", como ele chamava (Cohn, 2007, p. 20).

Muitos autores aderiram a alguma modulação da poesia-minuto nessas décadas. Charles Peixoto, Nicolas Behr, Eudoro Augusto, são muitos os exemplos daqueles ligados à geração mimeógrafo que optaram pela forma, dela extraindo, além da concisão, o despojamento métrico, sintático, vocabular e temático. Essa captação do momento, citada por Chacal, marca a prevalência de um sentimento de "agoridade" em um mundo que já não permitia mirar um futuro palpável. O olhar do artista, então, volta-se ao seu hic et nunc, e dele extrai seu substrato, em uma fusão entre vida e obra que perpassa boa parte dessa época de contracultura. Mais do que a operação oswaldiana de enxertar o cotidiano no poema em um calculado "artifício literário", Heloísa Buarque de Hollanda vê, nos marginais, o esforço de "poetização da experiência do cotidiano" em que vivências e sentimentos são transpostos enquanto tais ao texto, que se torna transparente na exibição daqueles: "Nesse gesto no qual o trabalho, a ciência, o progresso e o futuro deixam de ser valores fundamentais, o cotidiano passa a ser arte" (Hollanda, 2004, p. 112). O poema abaixo, de Chacal, poderia servir como uma "poética" a sintetizar sua geração:

\section{DIA PRIMEIRO E ÚLTIMO}

perdi o medo

perdi o metro

acho graça (Chacal, 2007, p. 341).

O título aponta essa concentração no presente, em que cada dia é vivido como sendo o único que importa. Nessa atmosfera, sexo e drogas tornam-se temas frequentes a jovens cujo ato de resistência é rejeitar o mundo "sério" do trabalho. Está-se longe da proposta estética oswaldiana, em perspectiva utópica, de repensar o país a partir de seu "vício de dependência" em relação à Europa; e, mais distante ainda, da ânsia revitalizante dos concretos para dirimir o atraso cultural brasileiro. Entre os marginais, o coletivo funde-se ao individual, certamente não sem perdas ou traumas, de tal modo que, em suas concepções, a transgressão possível é justamente a recusa aos rituais burgueses. ${ }^{4}$ Uma vida "alternativa", despojada da busca pelo progresso, reflete-se no poema: a ausência do medo do fracasso, do rótulo, da pobreza, é equiparada, por meio do paralelismo, ao abandono do metro no verso, quebra de esquadrias limitantes: a vida submetida ao sistema e à forma poemática fixa. Essa postura converge, inevitavelmente, a uma indiferença ("acho graça") que não é mais apenas irônica, pois transcende a lucidez avaliativa da ironia: trata-se do desbunde, visão anárquica e demolidora dos aparelhos de poder e das convenções públicas.

\footnotetext{
4 "É certo que o eu modernista se expunha em conjunção com a terra, i.e., assumia um caráter potencialmente público; que o poemapiada tinha, em consequência, uma latente conteundência política, ao passo que sua recepção tardia nos anos de 1970 o reduzia ao espaço do privado" (Lima, 2002, p. 161).
} 
As polêmicas acerca da validade dessa maneira de encarar o mundo são amplamente conhecidas, e excedem ao escopo deste trabalho. No que nos concerne, os poemetos marginais parecem crias diretas do poema-piada modernista, o que não impede que se salientem suas diferenças profundas. Como dito anteriormente nas falas de Chacal e Silviano Santiago, a coloquialidade, a objetividade e a irreverência são uma herança inconteste. Adicione-se, ainda, o valor conceitual, que nos autores de 70 estabelece outro pacto com o leitor: se apenas a extrema concisão, mais de quatro décadas depois das pílulas dos anos 20, não chocava mais o fruidor, seria então essa atitude frente à realidade, a despreocupação com a ideia de "denúncia" - comum nos precursores - e a atenuação da piada que desarranjaria a recepção? É um humor que se afasta da estrutura de anedota de deflagração de sentido através da disjunção entre o texto e o senso comum e adentra a seara da galhofa, da ridicularização total. Em se considerando esse aspecto, não é errado dizer que o epigrama de boa parte da geração mimeógrafo exige menos de seu receptor, pois raramente tem-se que "entender a piada", o que faz sua leitura ainda mais corrente e fluida.

Não se pode, entretanto, generalizar a poesia escrita nas décadas do regime militar brasileiro. Mesmo os ditos marginais apresentam marcantes diferenças em suas obras. Leila Míccolis, por exemplo, aprofunda a questão libertária nos relacionamentos a tal ponto, especialmente ao questionar a heteronormatividade e a poligamia, que seus escritos extrapolam o plano pessoal e ganham alçada coletiva. Além disso, muitos de seus poemas são menos "soltos" que de seus coetâneos, não raro metrificados, concentrando, na brevidade do comprimido literário, uma pontada de ataque que nasce na individualidade da fala e ascende ao questionamento generalizante:

Diferença

Meu mundo é violento e com razão:

na rua, se eu apanho, é covardia;

em casa, se eu apanho, é educação (Míccolis, 2013, p. 61).

De 1977, inserido na seção "Poemas infantis" do livro Silêncio relativo, o poema põe em cheque a educação de crianças a partir da contradição semântica de um mesmo vocábulo, o verbo "apanhar", e a elasticidade que ele adquire quando usado em diferentes contextos. Embora mais construído e irônico que a maioria das produções da época, nota-se que ainda assim a investida provocadora não é diretamente política, mas comportamental, tônica na autora, nesse aspecto em conexão com os demais representantes da linhagem do mimeógrafo.

Outro autor que surge colado a tal rótulo, para depois desgarrar-se dele em uma obra peculiar e irredutível a movimentos ou escolas, é Francisco Alvim. Conhecido pela heterogeneidade de sua produção, tem, entre poemas mais longos e reflexivos, um arsenal de epigramas, muitos de uma ou duas linhas, que até o fim da década de 70 flertavam com a piada mais tradicional, para, a partir dos anos 80, adquirirem uma natureza de "poesia-escuta", microfragmentos de discursos que ora evocam chavões ("Argumento / Mas se todos fazem", em Elefante) ora parecem uma minúscula narrativa, que lembram os microcontos contemporâneos: 5

Vida de artista

Meu tio

levou a vida que sempre quis -

era funcionário público

e nem a mulher sabia (Alvim, 2004, p. 191).

A fragmentação da fala, sem um "antes", "depois" ou qualquer contexto, retrata o próprio desmantelamento da experiência na contemporaneidade. No obscuro da incompletude,

\footnotetext{
${ }^{5}$ Não espanta que Alvim considere Dalton Trevisan - pai do microconto no Brasil - uma de suas principais influências, admitindo uma dívida "no sentido de que foi com ele que aprendi a elipse, o trato com a elipse, que é notável no Dalton. Mas uma coisa que me fascina nele - e eu aproximo de certo modo ao Nelson Rodrigues também - é o ouvido pra língua popular, para o coloquial popular, que é de uma riqueza, de uma poesia, de uma intensidade, de uma veracidade extraordinárias” (Alvim, 2012).
} 
enunciados que desvelam preconceitos e achaques correntes no cotidiano. Esses "nacos de discurso", lidos em sequência, dão a impressão de se estar no meio de uma rua movimentada, caminhando e captando pedaços de conversas vindas de emissores diversos. Esse "emprestar" a voz do outro no corpo do poema é a grande marca da obra de Alvim, e uma importante referência para as gerações seguintes de escritores. Veronica Stigger, por exemplo, em trabalho recente, materializa a "poesia-escuta" em uma fusão de performance, artes plásticas e literatura ao ir às ruas e às redes sociais captar de fato trechos ditos por anônimos, interrompidos, descontextualizados, como os poemetos de Alvim. Primeiramente apresentados em plaquetas em uma exposição do SESC de São Paulo, posteriormente virariam um livro de formato pequeno, artesanalmente editado, chamado Delírio de Damasco, de onde se lê:

Presta atenção:

ela não é bonita,

ela só parece bonita (Stigger, 2012, p. 62).

Em ambos os escritores, há uma zona cinzenta entre poesia e narrativa, frases soltas como representação da alteridade incógnita que circunda e invade o sujeito na cidade contemporânea. Trata-se de uma remodelagem conceitual no poema-piada, perdendo o tom anedótico (que exige um acabamento semântico) e a voz da "superioridade irônica" típica dos contos humorísticos, para virar um palco "neutro" em que os discursos se destroem por si mesmos, apenas através de sua exibição.

Além dos exemplos já citados, ao longo de toda a segunda metade do século $\mathrm{XX}$, autores de estilos e origens muito diferentes também se apropriaram, por vezes, da ideia da pílula, mas muito longe do desbunde da contracultura, como os jogos de palavra de Mário Quintana e os aforismos de Manoel de Barros. Um exemplo que chama a atenção é José Paulo Paes, autor de diversos epigramas cômicos que exploram recursos advindos de sua interação com a poesia concreta (trocadilhos, quiasmos, espacialidade, palavras-valise) para revitalizar o poema-piada, afastando-se desse em direção ao chiste, fagulha cômica que imanta o leitor, na deflagração do ludismo linguístico, em uma crítica universalizante:

Ocidental

\author{
a missa \\ a miss \\ o míssil (Paes, 2008, p. 170).
}

Aqui, a poesia-minuto nasce do trabalho com a linguagem, cuja manipulação na paronomásia faz brotar os termos parônimos que, com extrema concisão, remetem metonimicamente às religiões, à espetacularização midiática e à violência, faces interligadas da problemática sociedade ocidental contemporânea. O paralelismo quase total dos versos gera uma coesão visual e sonora que aciona o gatilho cômico e faz explodir, no último verso, a constatação crítica. Em Paes, o poema epigramático atinge, entre as décadas de 60 e 90, o ápice de seu apuro no labor da palavra, pois ele obtém, em pouquíssimas linhas, associações vocabulares múltiplas, sempre convocando uma amplitude social e política.

Nas últimas duas décadas, o "comprimido poético" continua a ser uma forma comumente encontrada, inclusive entre autores mais jovens, como Bruno Brum e Mariana Campos. Seja revitalizado em um humor mais cáustico, seja com um viés desacreditado, o fato é que a natureza sucinta da produção poética brasileira mantém seguidores, mesmo que eventuais, como Eduardo Sterzi, poeta que alterna textos mais longos e pílulas como a que se segue:

Cisma

Esqueça as palmeiras

e a Rua das Palmeiras

É outro o cenário (Sterzi, 2009, p. 108). 
De uma só visada, o poeta congrega menções a "Canção do exílio", de Gonçalves Dias; "Sambinha", de Mário de Andrade; e "Rua das Palmeiras", de Roberto Piva, justamente para afastá-los da contemporaneidade. Fica claro que a oposição ("cisma") entre o Romantismo e o Modernismo (encarnada, aqui, no poema oitocentista, talvez o mais retomado e parodiado de nossa literatura, inclusive por Oswald de Andrade) já não cabe no contexto do novo século, sintoma de um esgotamento natural da concepção de mundo dos modernos. Ao mesmo tempo, a famosa relação intertextual que Piva propõe a partir de Mário (em que o encantamento ao observar a metrópole neste adquire, naquele, uma alucinante e incômoda fusão do eu com a cidade, ambos fragmentados na aceleração das imagens do avião, do tapume e das pessoas) também é rejeitada pelo poema de Sterzi, que, em tom pós-utópico, já não adere a nenhum dos mitos citados (o país da natureza ou o país da industrialização urbana), mas sugere, pela omissão de um novo modelo, um cenário de "terra arrasada", em que nehuma identificação entre indivíduo e espaço é possível. O título, Cisma, tem sua origem etmológica no grego skhízo, termo comum no ideário contemporâneo, que ressoa ainda na palavra "outro" do poema, denotando tanto esse alheamento que o habitante sente em relação à cidade como o estranhamento do poeta de hoje em relação a todos os antecessores citados.

Outro tipo de manifestação do poema-minuto que vem ganhando força é sua postagem em redes sociais, como diversos autores têm feito no Twitter (o que motivou, em 2013, uma exposição no SESC Santo Amaro, em São Paulo, chamada "Tuiteratura") - sendo Fabrício Carpinejar o nome de maior destaque -, no Instagram (por exemplo, Verena Smit, artista plástica que funde imagem e poesia, lembrando aspectos da obra de Leonílson) e no Facebook, como André Vallias (2017) (Figura 1).

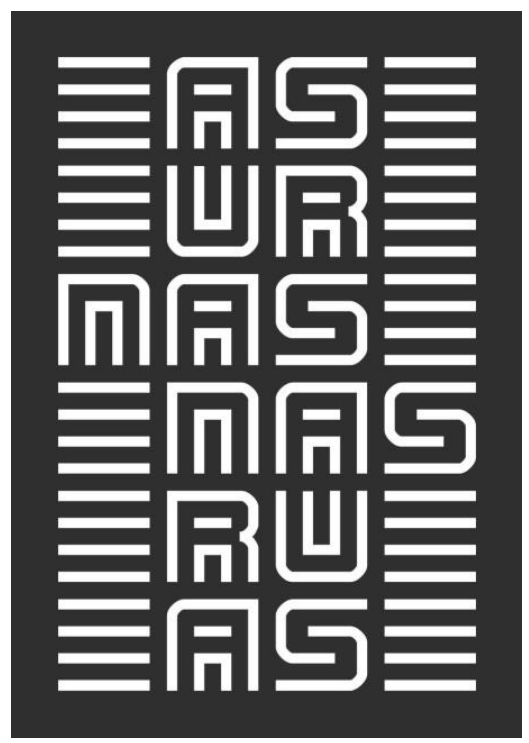

Figura 1 - Reprodução do poema Runas, de André Vallias.

Fonte: Vallias (2017).

O poema, chamado Runas, foi postado em 18 de maio de 2017 - dia em que Michel Temer foi fortemente pressionado a renunciar da presidência do Brasil após a divulgação de gravações comprometedoras. Há, então, um diálogo imediato com temas que perpassam a opinião pública, e que são repercutidos à exaustão nesse tipo de aplicativo. ${ }^{6} \mathrm{Na}$ relação anagramática runas/urnas/ruas, a "sorte lançada", tal qual nas pedras de adivinhação, de um país em colapso político. Nesses casos, a própria arquitetura dos sites de interação on-line constrói o cenário perfeito para a pílula literária: em meio a banalidades, selfies e outras mensagens

\footnotetext{
${ }^{6}$ Comentando outros poemas de Valias, Masé Lemos (2014) evoca a teoria da "ação direta" de Christophe Hanna, em que a poesia é proposta como "intervenção" a partir da consideração e da valorização do contexto político que se apresenta, incitando o autor à criação.
} 
características, instantâneos poéticos - em plena timeline - que desmobilizam o utilitarismo e a frivolidade cotidianos do código, gerando fagulhas estéticas que intervêm nesse meio digital.

Enfim, fica nítido que as diversas variações desses epigramas, desde as suas antecipações pré-modernas até o século XXI, são um formato incontornável no estudo da poesia brasileira, e constituem um frágil porém inegável fio conectivo de desenvolvimento ao longo do tempo. Como principal característica, marcam-se por desvirtuar a fruição tradicional de poesia, detida e cíclica, em uma experiência imediata e pontual. Hans Robert Jauss, em estudo sobre Baudelaire, propõe que a recepção de poesia passe pelos três atos do processo hermenêutico: uma primeira leitura perceptiva; a segunda, de interpretação retrospectiva; e a terceira, de inserção histórica. Todas, porém, mantêm uma coesão por meio daquele primeiro contato com o texto, vivência sensória que guia as outras investidas:

A compreensão estética, no texto poético, está orientada principalmente para o processo da percepção. Remete, portanto, hermeneuticamente ao horizonte de experiência da primeira leitura, o qual muitas vezes pode tornar-se visível em sua coerência formal e plenitude de significado - principalmente em textos historicamente distantes ou na lírica hermética - apenas após várias leituras (Jauss, 2002, p. 877).

O poema-piada e suas modulações, porém, parece unir todas as etapas logo na primeira visada, já que a deflagração do sentido embute-se na apreensão da faísca humorística e/ou conceitual que o poemeto abrange, já remetendo o leitor, historicamente, à tradição que o "gênero" já construiu em nossa tradição. Mais do que a concisão, o que chama a atenção é seu caráter de instantaneidade ao se apropriar do material vulgar da língua, em sua coloquialidade, e isolá-lo no cadinho do poema, transformando-o em um objeto estético ao mesmo tempo acessível a vários extratos de leitores e provocativo à sensibilidade desse receptor, que capta sua centelha em um flash catártico, espécie de happening que perturba a sua rotina. Sem prejuízo de uma poesia mais longa e reflexiva, essas pílulas são, renovadas ao longo do tempo, válidas propostas de intervenção desautomatizadora, comprimidos que, ao usar o discurso corrente contra si mesmo, colaboram para o seu questionamento.

\section{Referências}

ALVIM, Francisco (2004). Poemas [1968 - 2000]. São Paulo: Cosac Naify; Rio de Janeiro: 7Letras.

ALVIM, Francisco (2012). Entrevista ao Paiol Literário. Rascunho, Curitiba, n. 151. Disponível em: https://goo.gl/tfkCSF. Acesso em: 28 jun. 2018.

ANDRADE, Mário de (1931/1974). A poesia em 1930. In: ANDRADE, Mário de. Aspectos da literatura brasileira. 5. ed. São Paulo: Martins.

ANDRADE, Oswald de (1974). Obras completas - VII. 4. ed. Rio de Janeiro: Civilização Brasileira.

BANDEIRA, Manuel (1954/1997). Itinerário de Pasárgada. In: BANDEIRA, Manuel. Seleta de prosa. Rio de Janeiro: Nova Fronteira. p. 295-360.

BERGSON, Henri (1900/2007). O riso: ensaio sobre a significação da comicidade. 2. ed. São Paulo: Martins Fontes.

CAMPOS, Haroldo de (1965/1974). Uma poética da radicalidade. In: ANDRADE, Oswald de. Obras completas - VII. 4. ed. Rio de Janeiro: Civilização Brasileira. p. 9-59.

CAMPOS, Haroldo de; CAMPOS, Augusto de; PIGNATARI, Décio (1958). Plano piloto para poesia concreta. Noigrandes, São Paulo, n. 4. Disponível em: https://goo.gl/wVPSw4. Acesso em: 24 jun. 2018.

CANDIDO, Antonio (1993). A poesia pantagruélica. In: CANDIDO, Antonio. O discurso e a cidade. São Paulo: Duas Cidades. p. 225-244

CHACAL (2007). Belvedere [1971-2007]. São Paulo: Cosac Naify; Rio de Janeiro: 7Letras.

COHN, Sergio (2007). Nuvem cigana: poesia e delírio no Rio dos anos 70. Rio de Janeiro: Azougue. 
DERRIDA, Jacques (1992). Che cos'è la poesia. In: DERRIDA, Jacques. Points de suspension. Paris: Galilée. p. 303-308. FERREIRA, Ascenso (1981). Poemas de Ascenso Ferreira. Recife: Nordestal.

FISCHER, Luís Augusto (2009). Formação hoje: uma hipótese analítica, alguns pontos cegos e seu vigor. Literatura e Sociedade, São Paulo, v. 1, n. 11, p. 164-184.

FRANCHETTI, Paulo (1987). O riso romântico: notas sobre o cômico na poesia de Bernardo Guimarães e seus contemporâneos. Remate de Males, Campinas, v. 7, p. 7-17.

FRANCHETTI, Paulo (2012). O haikai no Brasil. In: FRANCHETTI, Paulo. Haikai: antologia e história. Campinas: Editora da Unicamp.

FRANCHETTI, Paulo (2013). Poesia contemporânea e crítica de poesia. Blog pessoal, 15 maio. Disponível em: https://goo.gl/ttAHov. Acesso em: 20 jun. 2018.

GUIMARÃES, Bernardo (1875). Produções satíricas e bocageanas de Bernardo Guimarães. E-book (Rede Memória) Disponível em: https://goo.gl/f1z45Z. Acesso em: 20 jun. 2018.

HOLLANDA, Heloísa Buarque de (1980/2004). Impressões de viagem: CPC, vanguarda e desbunde, 19601970. 5. ed. Rio de Janeiro: Aeroplano.

JAUSS, Hans Robert (1980/2002). O texto poético na mudança de horizonte da leitura. In: LIMA, Luiz Costa (Org.). Teoria da literatura em suas fontes. Rio de Janeiro: Civilização brasileira. v. 1.

LEMOS, Masé (2014). A mecânica lírica: alguns objetos contemporâneos. E-lyra, Porto, n. 3, p. 63-88.

LIMA, Luiz Costa (2002). Abstração e visualidade. In: LIMA, Luiz Costa. Intervenções. São Paulo: Edusp. p. 135-180. MÍCCOLIS, Leila (2013). Desfamiliares (1965-2012). São Paulo: Annablume.

MILLIET, Sergio (1952). Panorama da moderna poesia brasileira. Rio de Janeiro: Serviço de Documentação do M.E.S.

NUNES, Benedito (1972/1990). Antropofagia ao alcance de todos. In: ANDRADE, Oswald. A utopia antropofágica. São Paulo: Globo. p. 5-39.

PAES, José Paulo (2008). Poesia completa. São Paulo: Cia das Letras.

PRADO, Paulo (1925/1971). Poesia Pau-Brasil. In: ANDRADE, Oswald. Obras Completas. Rio de Janeiro: Civilização Brasileira. v. 7, p. 67-71.

ROLLAND, Francisco (1941). Adagios, proverbios, rifãos e anexins da lingua portugueza. Lisboa: Typografia Rollandiana.

SANTIAGO, Silviano (1989). A permanência do discurso da tradição no modernismo. In: SANTIAGO, Silviano. Nas malhas da letra: ensaios. São Paulo: Companhia das Letras. p. 94-123.

SANTO, Qorpo (1877a). Ensiqlopèdia, ou seis mezes de huma enfermidade: livro primeiro. Porto Alegre: Tip. Disponível em: http://www.pucrs.br/biblioteca/qorposanto. Acesso em: 25 jun. 2018.

SANTO, Qorpo (1877b). Ensiqlopèdia, ou seis mezes de huma enfermidade: livro segundo. Porto Alegre: Tip. Disponível em: http://www.pucrs.br/biblioteca/qorposanto. Acesso em: 25 jun. 2018.

STERZI, Eduardo (2009). Aleijão. Rio de Janeiro: 7Letras

STIGGER, Veronica (2012). Delírio de damasco. Florianópolis: Cultura e Barbárie.

VALLIAS, André (2017). Runas. Poema visual. Mensagem postada na fanpage do poeta no Facebook, 18 maio. Disponível em: https://goo.gl/5uxKkx. Acesso em: $1^{\circ}$ jul. 2018. 